\title{
An analysis of the Impact of Foreign Direct Investment by Chinese Companies in Thailand
}

\author{
Mathavee Keorite $^{\mathrm{a}}$, Gulzar Ali Shah Bukhari ${ }^{\mathrm{b}}$ and Pariya Chantarat ${ }^{\mathrm{c}}$
}

\begin{abstract}
Thailand has great inherent to become the investment base to serve as infrastructure and the gateway to Asian and world market for Chinese firms. China FDI has been an important driver of Thai economic development and therefore assisted in the process of economic recovery from Asian financial crisis. The paper sought to provide information and data on these forms of assistance and also, by way of data analysis, determine if the benefits achieved are mutual or whether China stands to gain alone in the various ventures. Most of the assistance is received through concessional loans approved by the Chinese government, Bank of China and made out to Chinese companies in order to provide foreign direct investment in Thailand. These loans are then repaid by the various government bodies and individual clients engaging the Chinese companies. The paper seeks to determine: "the impact of foreign direct investments by Chinese companies in Thailand" thereby discerning whether the impact is positive or negative. Literature and data used was obtained from the Journals, Internet and organizations involved in promoting investment in Thailand. The study found that FDI by Chinese companies leads to economic development by through human capital development, employment, and capital supply.
\end{abstract}

Keywords -Foreign Direct Investments(FDI), Thailand, Trade, Asian Economic Community(AEC), China, Asian

\section{1. introduction}

With the repaid growth of Chinese companies, many of them have started to mature into global players and explore the oversea markets. By 2013,

there are 89 Chinese companies listed in global fortune 500 [1]. Facing the dramatic changes in home country, more and more Chinese companies also realize it is time for them to move beyond the advantages that they have historically enjoyed: a large domestic market, competitive cost position, and strong state support. Passing the early stage of adaptation, Chinese companies' overseas networks have become increasingly more complicated. In 2012, China's outflow investment was $\$ 168,355$.26 million USD, which accounts for $12 \%$ of the total global outward FDI amount [2]. As Thailand has close cultural and ethnic ties with China and strategic location in Asian, in light of the China-Asian Free Trade Area (CAFTA), Thailand would play an important role in manufacturing and exporting of Chinese products to Asian region. In the 1987 to 2012 period, Chinese companies ${ }^{\text {ee }} 347$

${ }^{a}$ Mathavee Keorite

University: Xiamen University, PR China

${ }^{\mathrm{b}}$ Gulzar Ali Shah Bukharib

University: Xiamen University, PR China

${ }^{\mathrm{c}}$ Pariya Chantarat

Institute: Thai Industrial Standards Institute, Thailand investment projects in Thailand valued 102,433.9 million baht and covered all business sectors. China account only $0.78 \%$ of total Thai inward FDI value in 2007. This percentage

dramatically increased to $5.29 \%$ in 2012 [3]. China expanded its outward FDI in Thailand by $543.69 \%$ over the past 5 years. Follow the trend of the growth, China will play a more and more important role in inward FDI of Thailand. The regional integration of AEC will bring both opportunities and challenges to the Asian countries. The importance of FDI as a source of economic growth engine has been recognized by many, thus there is intense competition among Asian countries in attracting FDI. Exploring the current status of China's FDI status will help the authority to understand the trend of Chinese inward FDI and to create conducive business environment to retain the existing inflows as well as to persuade the remaining to invest.

This study will center on topics on the main employment opportunities created by foreign direct investment from Chinese companies and also discuss future projects that may be undertaken by the two countries. Eventually the research will attempt to answer the question as to whether investments by Chinese companies have a positive or negative impact on the Thailand economy.

\section{Background}

\subsection{Concepts of FDI}

According to the IMF and OECD definitions, direct investment reflects an investment made to obtain a lasting interest by a resident entity of one economy (direct investor) in an enterprise that is resident in another economy (the direct investment enterprise)[4]. Different investor might have different motives underlying FDI. The motives can be categorized into 4 types: 1) Resource-seeking FDI attempts to acquire particular resources at a lower cost than could be obtained in the home country; 2) Market-seeking FDI attempts to secure market share and sales growth in the target foreign market; 3) Efficiency-seeking FDI attempts to rationalize the structure of established resource-based or marketing-seeking investment in such a way that the firm can gain from the common governance of geographically dispersed activities; and 4) Strategic asset-seeking FDI attempts to acquire the assets of foreign firms so as to promote their long-term strategic objectives, especially advancing their international competitiveness [5].

\subsection{China's Outward FDI and Development of Trade Relationship between Thailand and China}


The motive of Chinese oversea: The United Nations[6] has identified five primary types of FDI from developing economies, which provide us with the framework to analyze Chinese outward FDI. According to United Nation, the motives for developing economies investment overseas, such as China can be classified as market-seeking, export-oriented, resource-seeking, technology-seeking and efficiencyseeking[6]. In 1978 China started to reform its economy by opening up trade to the outside world and by 1990 six special economic zones were established, including the Shanghai Pudong zone, which was a pioneer in attracting foreign capital[7]. Overall, the Chinese economic reform has been a spectacular economic success which has generated rapid economic growth over two decades and the country has moved from a centrally-planned economy towards a market economy; especially since China became a member of the World Trade Organization (WTO) in 2001.

According to $\mathrm{Hu}[7]$, before the reform, all the companies were state owned. In fact there were no entrepreneurs. After 20 years of growth, company ownership has undergone unprecedented changes. On the whole, non-state-owned companies can now be more involved in sectors that used to be monopolized by state-owned companies. Except for the sectors of electricity, telecommunications, oil and the defense industry, most of the other sectors are privately held. Development in China and most East Asian countries occurred most successfully because states intervened to consciously promote social transformation and industrialization. The state did this by use of selective protection of their industries from cheap imports from the established overseas industries; they intervened to secure investment in dynamic sectors; discipline of both capital and labor through corrective measures against capital export and worker rights; and the forcible removal of people from land in order to secure labor force for the new industries. In terms of wage rates, it is to be noted that although they are rising in China's coastal areas, labor wages in the inner central and western provinces are, however, still relatively much lower than their counterparts in many other Eastern Asian countries. The large size of the population, coupled with the rising income of the Chinese people in recent years, has accelerated China's import potentials. Moreover, the increases in all kinds of production from the strong supply bases also stimulate sharp import growth, particularly in terms of high technological products, energy products, basic commodities, raw materials, components and spare parts, among others. The improvements in the standards of living among the Chinese since the opening up of the country in the late 1970s also increased China's imports of some more diversified types of finished products.

From 1991 to 2002, the total trade of the two countries increased to about 31 percent and then increased more sharply after China's accession to the World Trade Organization (WTO) on December 11, 2001. In the1987 to 2012 period, Chinese companies ${ }^{\text {ee }} 347$ investment projects in Thailand valued 102,433.9 million baht and covered all business sectors. China account only $0.78 \%$ of total Thai inward FDI value in 2007. This percentage dramatically increased to $5.29 \%$ in 2012[3]. China expanded its outward FDI in
Thailand by $543.69 \%$ over the past 5 years. Follow the trend of the growth, China will play a more and more important role in inward FDI of Thailand.

\subsection{Future Trend of Economic Relations}

According to the agenda, the building of CAFTA has to undergo three stages, taking about another one decade. The first stage was from 2002 to 2010; the second stage is from 2011 to 2015, when the other four ASAEN new member states starting the zero tariffs and the focus of CAFTA will expend to trade of service and market of investment. The third stage is after 2016, and CAFTA will continue to be more consolidated and perfect. China and Asian-10 have signed the "Second Protocol to Amend the Agreement on Trade in Goods of the Framework Agreement on Comprehensive Economic CoOperation between the Association of Southeast Asian Nations and the people's Republic of China " in Kuala Lumpur, the capital of Malaysia on October 29, 2010. Global economic meltdown and the re-emergence of global trade protectionism have once again highlighted the importance of regional economic cooperation. There are complementarities between China and Thailand economically ascribing to the features of diversities of these two countries in the empowerment of natural resources, economic development stage, and the public consumption. Since the governments of the two countries have recognized the importance of the further economic cooperation are in the benefit of the people welfare, and many effective initiatives are being adopted in particular in the form of seminars, study visits, program training cooperation projects and Est., that can greatly improve both sides to understand each other's political, economic and cultural situation. Moreover, the coordination of the two governments are going on so far smoothly, there are good reasons to trust that the relationship between China and Thailand in the next five years will be further enhanced.

According to Chinese Prime minister, Li Keqiang held talks with Thailand counterpart Prayut Chan-o-cha in Beijing on $23^{\text {rd }}$ December,2014 and pledged to further boost bilateral relationship between the two countries. The two observed a currency swap deal and three other cooperation documents as part of the efforts to raise bilateral trade to 100 billion USD by 2015. They have met in Bangkok and have witnessed the signing of projects in some economic sectors such as agriculture and railway deals. The target of two sides has been set to increase travelers in two sides by 2016. With 2015 marking the 40th anniversary of ties between the two nations, Premier Li expressed hope that relations would continue to deepen. Thailand is a close neighbor of China, and a moderator in China's relations in Asian. China-Thailand relations play a positive role in regional peace and stability. Leaders from both sides have met since October in international summits including the Asia-Europe meeting, the APEC leaders' meeting, the Asian Summit and the Greater Mekong Sub-region Summit. Analysts believe the agreements underline China's wish to extend cooperation with Thailand in various fields. They also signify a concrete step in a joint vision of regional inter-connectivity[8]. 


\section{Methods of this Study}

\subsection{Sample}

This study use form of close-ended questionnaire as instrument. This survey instrument was developed for the purpose of collecting the main data for the study. We has conducted this study in various organizations conversant with FDI issues. Primary data was obtained using questionnaires. The target population were bureaucrats and employees of various organizations conversant with FDI issues. Purposive sampling technique was employed in selecting a sample size of 30 persons to whom questionnaires were administered.

\subsection{Instrument Development}

The survey instrument used in this study is composed of 2 parts. The first part includes a number of demographic questions such as gender, age, organization and education level. Part 2 deals with statements on the impact of the various projects carried out in Thailand by Chinese companies on Human capital development, employment and capital supply, respectively. Each of job stressors was measured on a fivepoint Likert Scale in which 1 indicated "strongly disagree", 2 indicated "disagree", 3 indicated "undecided", 4 indicated "agree" and 5 indicated "Strongly agree".

\subsection{Data Analysis Method}

A survey research design was used in this study. Primary data was obtained using questionnaires. The target population was employees of various organizations conversant with FDI issues. Purposive sampling technique was employed in selecting a sample size of 30 persons to whom questionnaires were administered.

\section{Results and Analysis}

\subsection{Introduction}

This study has objective that was to determine the impact of FDI by Chinese companies in Thailand. A sample of 30 informants drawn from the top level management from various organizations in Thailand conversant with FDI issues was used. Out of the 30 questionnaires sent out, 30 questionnaires, representing 100\% were received back, 30 questionnaires representing $100 \%$ were received back fully completed making. According to Babbie[9], a response of over 50\% and above is adequate for analysis thus $100 \%$ is even better. Majority of the respondents, that is more than $95 \%$ were of the opinion that Follow the trend of the Economic growth, China will play a more and more important role in inward FDI of Thailand. $61.5 \%$ of respondents were of opinion that FDI by Chinese companies is likely to be an engine of Thailand's economic growth. Because FDI inflow may lead to manufactured exports thus improving balance of payments. In addition, $50 \%$ of respondents were of the opinion that Thailand does not actively pursue export-led growth strategy thus it is unable to reap enormous benefits from FDI from china companies. Majority of the respondents had reason to believe that As Thailand has close cultural and ethnic ties with China and strategic location in Asian, in light of the ChinaAsian Free Trade Area (CAFTA), Thailand would play an important role in manufacturing and exporting of Chinese products to Asian region. Being an important role in manufacturing and exporting of Chinese products do not have enough resources to meet its development goals and thus the need to attract more foreign investment to complement the local investment. In this regard we expect economic growth rate of Thailand to grow through increased investments. Furthermore FDI provides a major source of capital which brings with it upto-date technology contributing to economic growth. Those who agreed that dependence on foreign investments will have negative effect on growth and the distribution of income in Thailand, Chinese investors in Thailand have been facing Labor Problems; Wage rates in Thailand are higher than in China (about 30-50\% higher). The much higher labor turnover rates in Thailand lead to limitations in incentives for investment in labor-skills development indicated that dependence on them will cause distortion in incomes and capital will be withdrawn when there are signs of instability economically or politically and Chinese FDI are mainly skewed in the industrial zone and capital city.

\subsection{Reliability}

The internal reliability of the items was verified by computing the Cronbach's alpha[10,11]. Nunnally[11] suggested that a minimum alpha of 0.6 which the study benchmarked against . The Cronbach alpha estimated for human Capital Development was 0.618, Employment was 0.634, Capital supply was 0.701 . All the scales were significant, having an Alpha above the prescribed threshold of 0.6. When all scales were combined, the Cronbach's Alpha became 0.654.

\subsection{Impact of FDI by Chinese companies leads to economic Development}

\subsubsection{Economic Development through Human Capital}

Respondents' agreement level with statements on the impact of the various projects carried out in Thailand by Chinese companies on human capital development. The study sought to find out the respondents' agreement level with statements on the impact of the various projects carried out in Thailand by Chinese companies on human capital development. According to the findings, the respondents agreed that Chinese companies train domestic workers who later transfer skills and knowledge acquired to local firms as shown by a mean of 3.60. This is in line with Blomström and Kokko[12] who stated that workers already trained by or worked in foreign affiliates may be potentially available to work in domestic firms or start their own firms in the same industry.

The respondents were undecided that FDI by Chinese companies has led to development of quality human capital through diffusion of new technology and ideas as shown by a mean of 3.53. Blomström and Kokko[12] add that training and human capital development are often more important in 
service industries because training in service sectors is more directly focused on strengthening the skills and know-how of employees, while training in manufacturing sectors is often to facilitate the introduction of new technologies embodied in machinery and equipment.

The respondents agreed that FDI by Chinese companies has brought transfer of foreign useful skills as shown by a mean of 3.30. Kumar and Pradhan[13] indicated that FDI usually flows as a bundle of resources, including organizational and managerial skills, marketing know-how and market access through the marketing networks of multinational enterprises (MNEs).

The respondents were undecided that Chinese firms after entering Thailand market demonstrate their advanced technology and Thai employees afterward adapt or imitate them as shown by a mean of 3.17. New growth theories posit that transfer of technology through FDI in developing countries is especially important because most developing countries lack the necessary infrastructure in terms of an educated population, liberalized markets, economic and social stability that are needed for innovation to promote growth[14].

The result in Table 1 shows that the respondents agreed that FDI has brought competition, this increase in competition that occurs as a result of Chinese firms entry forces domestic firms to introduce new technology and/or work harder as shown by a mean of 3.47. The preference for export-oriented FDI has led to intensive competition among developing countries seeking to attract such investment and to a convergence among policy and promotional environments of these countries in pursuit of FDI [15].

Looking at Table 2, Employment; Respondents have agreement with statements on the impact of the various projects that carried out in Thailand market by Chinese companies on employment creation.

TABLE 1 ECONOMIC DEVELOPMENT THROUGH HUMAN CAPITAL

\begin{tabular}{|l|c|c|}
\hline \multicolumn{1}{|c|}{ Human Capital } & Std. \\
\hline $\begin{array}{l}\text { Chinese companies train domestic workers who later } \\
\text { transfer skills and knowledge acquired to local firms } \\
\text { FDI by Chinese companies has led to development of } \\
\text { quality human capital through diffusion of new } \\
\text { technology and ideas }\end{array}$ & 3.60 & .724 \\
$\begin{array}{l}\text { FDI by Chinese companies has brought transfer of } \\
\text { foreign useful skills } \\
\text { Chinese firms after entering Thailand market } \\
\text { demonstrate their advanced technology and Thailand } \\
\text { afterward adapt or imitate them }\end{array}$ & 3.53 & .571 \\
$\begin{array}{l}\text { FDI has brought competition. This increase in } \\
\text { competition that occurs as a result of Chinese firms } \\
\text { entry forces domestic firms to introduce new } \\
\text { technology and/or work harder }\end{array}$ & 3.47 & .837 \\
\hline
\end{tabular}

From the findings, the respondents agreed that FDI by Chinese companies lead to job creation in Thailand market as shown by a mean of 4.00. Especially lead to job creation or employment in special economic zone and Industrial real estate in Thailand.
They normally promise increased capital, employment and foreign exchange for less developed countries [16].

The respondents were undecided that Chinese companies are discriminative providers of employment because they mainly employ non-professionals and only casual laborers as shown by a mean of 3.20 .

The respondents were undecided that Chinese companies have led to very high competition amongst local companies thus leading to their down fall and thus loss of employment as shown by a mean of 3.50. FDI can lead to conflict between private benefits and social benefits, especially if such FDI is protected from competition [15].

The respondents were undecided that Chinese FDI has led to exacerbating inter-regional economic and employment disparities as a result of the uneven distribution of FDI in Thailand market as shown by a mean of 3.20. This contrasts with Onjala[17], who argued that China will continue offering economic aid within its available resources and strengthen assistance for human resources development in Thailand. The respondents disagreed that employment terms and conditions by Chinese companies are favorable as shown by a mean of 3.03 .

\section{TABLE 2 ECONOMIC DEVELOPMENT THROUGH EMPLOYMENT}

\begin{tabular}{|l|c|c|}
\hline \multicolumn{1}{|c|}{ Employment } & Mean & $\begin{array}{c}\text { Std. } \\
\text { Deviatio } \\
\text { n }\end{array}$ \\
\hline $\begin{array}{l}\text { FDI by Chinese companies lead to job creation in } \\
\text { Thailand } \\
\text { Chinese companies are discriminative providers of } \\
\text { employment because they mainly employ non } \\
\text { professionals and only casual laborers }\end{array}$ & 4.00 & .788 \\
$\begin{array}{l}\text { Chinese companies have led to very high competition } \\
\text { amongst local firms thus leading to their down fall and } \\
\text { thus loss of employment } \\
\begin{array}{l}\text { Chinese FDI has led to exacerbating inter-regional } \\
\text { economic and employment disparities as a result of the } \\
\text { uneven distribution of FDI in Thailand }\end{array}\end{array}$ & 3.50 & .720 \\
$\begin{array}{l}\text { Employment terms and conditions by Chinese companies } \\
\text { are favorable }\end{array}$ & 3.03 & .761 \\
\hline
\end{tabular}

\subsubsection{Economic Development through Capital Supply}

The result in table 3 shows that the respondents' agreement with statement on the impact of the various companies carried out in Thailand by Chinese companies on Capital supply. From the findings illustrated in the table 3 , the respondents agreed that FDI acts as a means of supply of foreign currency thus stabilizing the exchange rate in Thailand as shown by a mean of 3.13. FDI plays a twofold function by contributing to capital accumulation and by increasing total factor productivity[18].

The respondents were undecided that FDI by Chinese companies is likely to be an engine of Thailand's economic growth, because FDI inflow may lead to manufactured exports

thus improving balance of payments as shown by a mean of 3.57. FDI is viewed as a major stimulus to economic growth (see, for example, $[19,20])$. These authors argue that foreign 
investors can provide the capital, technical and marketing know-how needed for growth.

The respondents were undecided that capital inflows at substantial rates through FDI will reduce the need for borrowing. This will reduce the debt-service ratio, which can be a real drain on heavily indebted countries, such as Thailand's economic as shown by a mean of 3.60. FDI can also have adverse balance-of-payments if inputs need to be imported. Foreign reserves can also diminish when profits are returned to their countries[20].

TABLE 3 ECONOMIC DEVELOPMENT THROUGH CAPITAL SUPPLY

\begin{tabular}{|l|c|c|}
\hline \multicolumn{1}{|c|}{ Capital Supply } & Std. \\
Deviation
\end{tabular}

The respondents were undecided that China's FDI crowded out national savings, and a reduction in domestic savings could lead to further increase on the dependency on foreign capital, thus leaving Thailand vulnerable and tied up to any requirements that are skewed towards China as shown by a mean of 3.03. They argue that FDI can have adverse effects on employment, income distribution, and national sovereignty and autonomy.

The respondents were undecided that Thailand economic development does not actively pursue export-led growth strategy thus it is unable to reap enormous benefits from FDI from china companies as shown by a mean of 2.53 . Bornschier and Chase-Dunn [21] claimed that foreign investment creates an industrial structure in which monopoly is predominant, leading to what they describe as "underutilization of productive forces".

\subsubsection{Impact of FDI by Chinese companies}

The respondents listed various positive impacts carried out in Thailand by China companies; such as Promotes economic growth; Growth of infrastructure; can generate an inflow of physical and human capital to the host country; FDI as a source of technology spillovers; Creation of employment; Supplements the domestic savings and of a nation by bringing in non debt-creating foreign capital resources; Expanding and/or diversifying the production capacity of Thailand which, in turn, is expected to enhance trade; Access to new technology and skills enhancement ; Increased tax revenues to government. The few negative impacts of FDI that were mainly agreed that FDI by Chinese companies in Thailand has a net positive effect on national economic welfare and highlighted various positive impacts as the main reasons.

The majority of respondents indicated that Thailand Government should formulate FDI policies that stimulate and create conducive environment for foreign government to invest in Thailand. The government should also ensure there is no duplication and overlap of investment matters on spearheading and overseeing.

\subsection{Descriptive Statistic}

TABLE 4 DESCRIPTIVE STATISTIC

\begin{tabular}{|l|c|c|}
\hline \multicolumn{1}{|c|}{ Variables } & Mean & Std. Deviation \\
\hline Impact of FDI on Thailand Economic Development & 3.326 & .326 \\
Human Capital Development & 3.390 & .467 \\
Employment & 3.400 & .421 \\
Capital Supply & 3.186 & .537 \\
\hline
\end{tabular}

From the findings illustrated in the table 4 , the respondents were agreed that FDI by Chinese companies has led to development of quality human capital as shown by a mean of 3.390. Blomström and Kokko[11] add that training and human capital development are often more important in service industries because training in service sectors is more directly focused on strengthening the skills and know-how of employees, while training in manufacturing sectors is often to facilitate the introduction of new technologies embodied in machinery and equipment.

The respondents agreed that FDI by Chinese companies lead to employment as shown by a mean of 3.40. From the finding illustrated in the table above, the respondents agreed that FDI acts as a means of Capital Supply in Thailand as shown by a mean of 3.186 .

\subsection{Model Summary}

TABLE 5 MODEL SUMMARY

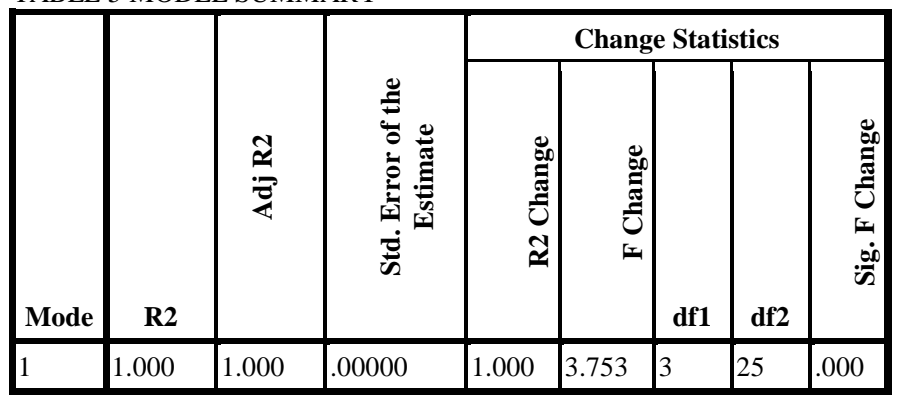

a. Predictors: (Constant), Human capital, Employment, Capital Supply.

b. Dependent Variable: Economic Development due to China FDI.

The result is in table 5 shows that the coefficient of determination (the percentage variation in the dependent variable being explained by the changes in the independent 
variables) R2 equals 1.000 that mean human capital development, employment and capital supply explain $100 \%$ percent of economic development due to FDI. The P-value of 0.000 (Less than 0.05) implies that the model of economic development due to FDI is significant at the 5 percent significance

\subsection{Pearson Correlation Analysis}

The analysis in table 6 , two predictor variables are said to be correlated if their coefficient of correlations is greater than 0.5 . In such a situation one of the variables must be dropped from the analysis. As shown in table 6, none of the predictor variables had coefficient of correlation between themselves more than 0.5 hence all of them were included in the model. The matrix also indicated high correlation between the response and predictor variables.

TABLE 6 PEARSON CORRELATION ANALYSIS

\begin{tabular}{|c|c|c|c|c|c|}
\hline & Variables & 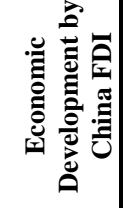 & 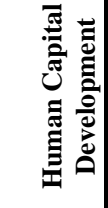 & 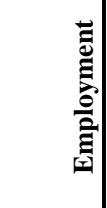 & 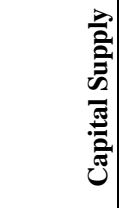 \\
\hline 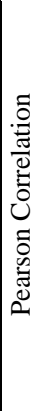 & $\begin{array}{l}\text { Impact of FDI on } \\
\text { Thailand and } \\
\text { Economic } \\
\text { Development } \\
\text { Human Capital } \\
\text { Development } \\
\text { Employment } \\
\text { Capital Supply }\end{array}$ & $\begin{array}{l}.461 \\
.720\end{array}$ & $\begin{array}{l}.240 \\
.495\end{array}$ & $\begin{array}{l}1.000 \\
-.152\end{array}$ & 1.000 \\
\hline
\end{tabular}

\subsection{Regression Analysis}

From the findings illustrated in the table 7, the established multiple linear regression equation becomes: $\mathrm{Y}=-1.746+$ $0.333 \mathrm{X} 1+0.331 \mathrm{X} 2+0.346 \mathrm{X} 3$

As shown in the table 7 , Constant was -1.746 shows that if human capital development, employment, and capital supply were all rated as zero, Thailand Economic Development due to FDI rating would be decrease 1.746.

Human Capital Development was X1 , X1 was 0.333 shows that one unit change in human capital development result in 0.333 units increase in Thailand Economic Development due to FDI.

Employment was $\mathrm{X} 2, \mathrm{X} 2$ was 0.331 shows that one unit change in Employment results in 0.331 units increase in Thailand Economic Development due to FDI.

Capital Supply was X3, X3 was 0.346 shows that one unit change in Capital Supply results 0.346 units increase in Thailand Economic Development due to FDI.

\section{CONCLUSION}

From the data analysis the researcher concludes FDI by Chinese companies has great effect on Capital Supply which leads to economic development in Thailand.

The further study concludes that FDI by Chinese companies leads to creation of employment in Thailand. Finally the study concludes that FDI by Chinese companies has led to development of quality human capital through transfer useful skills and diffusion of new technology and ideas.

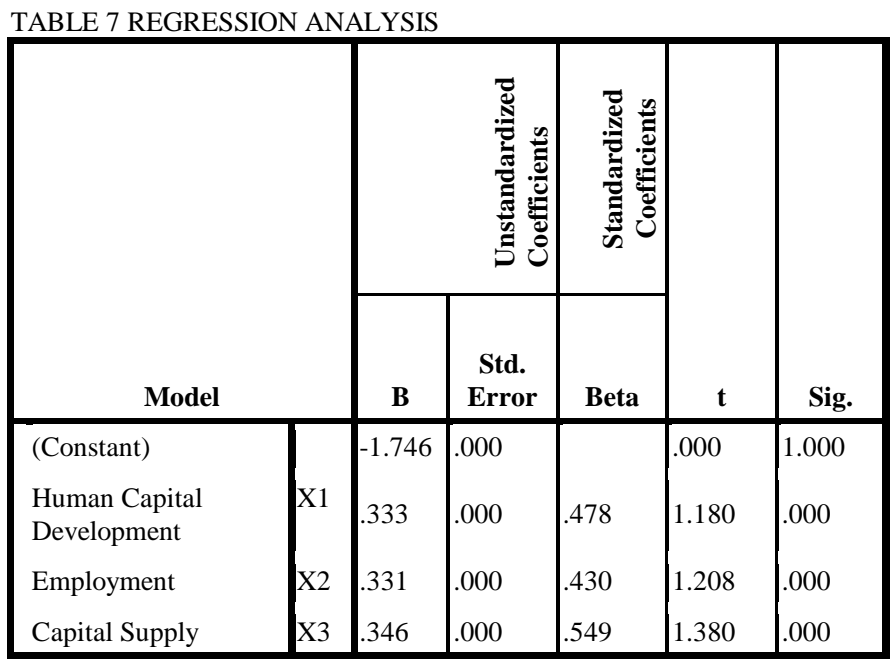

a. Dependent Variable: The impact of FDI on Thailand Economic Development

\section{Recommendation}

From firm internal resource and capability respect, Looking at table 8, there are several recommendations can be shared based on this study to help Chinese investors to achieve sustainable business development in Thailand.

\section{Limitation of The Study}

Although this study may provide insight into the connection of Chinese investors and the informants drawn from the top level management from various organizations in Thailand conversant with FDI issues relationship, it has many limitations.

First, this study employed a survey over a short period of time. So this study does not fully explore the main paths of the top level informants(e.g. Ministry of Commerce, Department of Custom). This study informants drawn from the top level management from various organizations. The majority of organizations are Ministry of Industry, Ministry of Finance, Research and Development sectors, University, Private sectors, respectively.

The second limitation is in regard to respondents. Although all respondents were the top level management from various organizations in Thailand conversant with FDI issues, thus the collected data are therefore believed to be accurate, but the feedback rate is low. To expand the sample size which can cover more various organization in Thailand conversant with FDI issues may help to have a complete understanding of The Impact of FDI by Chinese companies. 
Proc. of The Second Intl. Conf. On Advances In Economics, Social Science and Human Behaviour Study - ESSHBS 2015 Copyright $(\odot$ Institute of Research Engineers and Doctors, USA .All rights reserved.

ISBN: 978-1-63248-076-7 doi: 10.15224/ 978-1-63248-076-7-53

TABLE 8 SUMMARY OF RECOMMENDATION

\begin{tabular}{|c|c|}
\hline Organization & $\begin{array}{r}\text { Recommendation } \\
\end{array}$ \\
\hline $\begin{array}{l}\text { From } \\
\text { Government } \\
\text { sectors }\end{array}$ & $\begin{array}{l}\text { Recommendation of Thailand Government are } \\
\text { following; Ministry of Revenue : Chinese companies } \\
\text { need to understand the Regulations and Tax Laws in } \\
\text { the Kingdom of Thailand. }\end{array}$ \\
\hline $\begin{array}{l}\text { Ministry of } \\
\text { Industry }\end{array}$ & $\begin{array}{l}\text { Chinese companies needs to understand the Labor Law } \\
\text { and Regulations in Thailand. Chinese companies also } \\
\text { need to accelerate the learning and following of } \\
\text { Oversea Local Laws and Regulations. Eventually, } \\
\text { Regulators should create Regulations clearly. } \\
\text { Regulators also need to evaluate by checking update of } \\
\text { those Regulations. }\end{array}$ \\
\hline Private Sectors & $\begin{array}{l}\text { joint venture can help Chinese companies to access the } \\
\text { limited sourcing/distribution channel. However } \\
\text { Chinese companies, particularly those of SOE's } \\
\text { backgrounds, lack the connections with local partners } \\
\text { in Thailand. Gaps in connection and relationship not } \\
\text { only cause the less efficient business management but } \\
\text { also induce a higher-degree of malpractices and non- } \\
\text { merit in doing business. Moreover, Chinese } \\
\text { companies, particularly those of Suppliers of Thailand } \\
\text { companies, lack of concern and control consistency of } \\
\text { raw material and intermediate product. These not only } \\
\text { cause the more cost business management but also } \\
\text { induce a degree of satisfaction of local partners in } \\
\text { Thailand in doing business. Chinese companies need } \\
\text { to understand the value and importance of intellectual } \\
\text { property in overseas market. Meanwhile, Chinese } \\
\text { companies need to improve the ability in generating } \\
\text { patents and the ability to translate patents into } \\
\text { economic value. }\end{array}$ \\
\hline
\end{tabular}

Note: Data obtained from interviews.

\section{FUTURE RESEARCH}

In this paper the researchers have made an attempt to uncover the connection of Chinese investors and the informants drawn from the top level management from various organizations in Thailand conversant with FDI issues was used by estimating equation. However, the number of the top level management from various organizations in Thailand conversant with FDI issues included in the sample we used in estimating China's outward FDI in Thailand is substantially small sample. Thus, the first direction of research are to expand the sample size and to do fully explore the main paths of the top level informantse.g. Ministry of Commerce, Department of Custom. A second direction of further research is to consider the impact of other potential factors that could have an impact of FDI by Chinese companies from instructional based view.

\section{Acknowledgment}

Thanks the support of Thai Industrial Standards Institute, Ministry of Industry, Department of Revenue, Ministry of Finance, Bangkok, Thailand.

\section{REFERENCE}

[1] CNN Money. (2013), A New perspective on the corporate world. Fortune Magazine. [Online]. Available: http://money.cnn.com/magazines/fortune/global500/2012/globalcompany-growth/(accessed March $\left.14^{\text {th }}, 2015\right)$.

[2] UNCTAD. (2013). FDI/TNC database. [Online]. Available: http//:www.unctad.org/fdistatistics(accessed April 25 ${ }^{\text {th }}$,2015).

[3] BOT. (2013), "Foreign direct investment classified by country". [Online]. Available:

http://www.bot.or.th/ STATISTICS(accessed May $1^{\text {st }}, 2015$ ).
[4] IMF, Balance of Payments Manual, 5th edition, International Monetary Fund, Washington: International Monetary Fund, p. 86, 1993.

[5] J. H. Dunning(1993), Multinational Enterprises and the Global Economy, Wokingham, Addison Wesley, Reading, MA., p. 20.

[6] United Nation(1993), "Transnational Corporations from Developing Countries: Impact on Their Home Countries", New York, United Nations.

[7] Hu V., (2005), “The Chinese economic reform and Chinese entrepreneurship", [Online] Available:

http://www.uoc.edu/symposia/caixamanres/jornadaeconomia/2005/ eng/vicky_hu.pdf.

[8] CCTVNEWS (2014), "China, Thailand eyeing $\$ 100$ billion trade by 2015", [Online]Available: http://www.news.cn (accessed May $1^{\text {st }}$ ,2015).

[9] Babbie, E. (2002), "The basics of social research" (2nd ed.). Belmont, CA: Thomson Learning.

[10] Cronbach, L. J. (1951), "Coefficient alpha and the internal structure of tests". Psychometrika, 16(3), pp 297-334.

[11] J. C. Nunnally (1978), "Psychometric Theory", 2nd ed. New York: McGraw-Hill, pp 245.

[12] Blomstrom, M, Kokko, A (1998),"Multinational corporations and spillovers", Journal of Economic Surveys, Vol. 12, pp 24.

[13] Kumar N. and Pradhan J.P. (2002) "Foreign direct investment, externality and economic growth in developing countries: Some empirical explorations and implications for WTO negotiations on investment", Research and information system, New Delhi India.

[14] Bengoa and Sanchez-Robles(2003), "Foreign direct investment, economic freedom and growth: new evidence from Latin America", European Journal of Political Economy, Vol. 19, pp 529-545.

[15] Alvin G. Wint, Densil A. Williams, (2002), "Attracting FDI to developing countries: A changing role for government?", International Journal of Public Sector Management, Vol. 15 Iss: 5, pp.361 - 374 .

[16] Ishikawa, Horiuchi, “Strategic foreign direct investments in vertically related markets", [Online] Available: http://www.rieti.go.jp/en/

[17] Onjala J.,"A scoping study on China - African Economics Relations: the case of Kenya", African Economic Research Consortium (AERC), Nairobi, Kenya (5th March 2008).

[18] Nath, K.E., Vo, N.,"Foreign investment strategies and subnational institutions in emerging markets: Evidence from Vietnam", Journal of Management Studies, Vol. 42, pp. 63-93, 2005.

[19] Anis Chowdhury, Iyanatul Islam(1993), "The Newly Industrialising Economies of East Asia", Routledge.

[20] Gary Rodan(1997), "Civil society and other political possibilities in Southeast Asia" Journal of Contemporary Asia, Vol 27, pp 156-178

[21] Bornschier, G., Chase-Dunn D.W.,"Government policies towards foreign direct investment”, In Wignaraja, G.(Eds),Competitiveness Strategy in Developing Countries:

A Manual for Policy Analysis, Routledge, London, 2002. 
Proc. of The Second Intl. Conf. On Advances In Economics, Social Science and Human Behaviour Study - ESSHBS 2015

Copyright (C) Institute of Research Engineers and Doctors, USA .All rights reserved.

ISBN: 978-1-63248-076-7 doi: 10.15224/ 978-1-63248-076-7-53

\section{ABOUT THE AUTHOR}

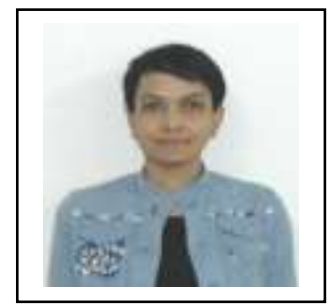

Mathavee Keorite is a PhD candidate of School of Economics, Xiamen University, PR China. She works with Ministry of Industry, Thailand. Her current position is

Professional Standards Officer. She obtained master degree of Industrial Economic and is currently pursuing a Ph.D degree at Xiamen University. Her research interests include International trade, Foreign Direct Investment and its impacts , and Industrial investment Policy

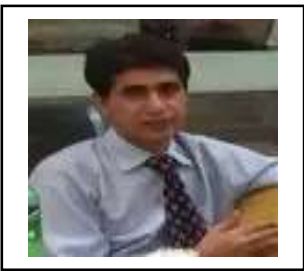

Gulzar Ali Shah Bukhari is a PhD candidate of Institute of Education, Xiamen University, Fujian, PR China. he work at Federal Government Public School, Risalpur Cantt, Pakistan. His research interests include Education systems of Pakistan and its impact

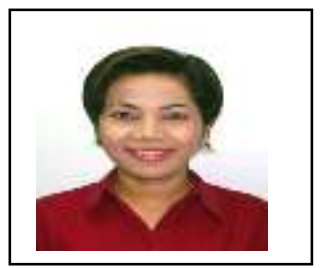

Pariya Chantarat is a Professional Standards officer. She works as Regulator, Policy maker and auditor with Thai Industrial Standards Institute(TISI), Ministry of Industry, Bangkok, Thailand 